\title{
Establishment of Four Native Tree Species for Potential Revegetating of Tin-Mined Land in Bangka Island, Indonesia
}

\author{
E. Nurtjahya Universitas Bangka Belitung, Indonesia \\ D. Setiadi Departemen Biologi, Institut Pertanian Bogor, Indonesia \\ E. Guhardja Departemen Biologi, Institut Pertanian Bogor, Indonesia
}

Muhadiono Departemen Biologi, Institut Pertanian Bogor, Indonesia

Y. Setiadi Laboratorium Bioteknologi Hutan dan Lingkungan, Pusat Penelitian Sumberdaya Hayati dan Bioteknologi, Institut Pertanian Bogor, Indonesia

\begin{abstract}
A research study was conducted to investigate revegetation of tin-mined land using mixed native tree species on Bangka Island, Indonesia. Natural plant succession on these sites is very slow. Consequently, the objective of this study was to evaluate ten native tree species for their suitability, and develop protocols for the rapid restoration of sand tin tailings. An experiment evaluated three levels of planting distance $(4 \times 4 \mathrm{~m}$, $2 \times 2 \mathrm{~m}, 1 \times 1 \mathrm{~m}$ ), five levels of soil treatment (control, plus slimes tailings powder, legume cover crops (LCC), LCC and humic acid, and LCC and topsoil) with each treatment replicated three times. A total of 3345 seedlings were planted in 45 plots, each $12 \times 12 \mathrm{~m}$. Four species i.e. Hibiscus tiliaceus L. (Malvaceae), Ficus superba Miq. (Moraceae), Calophyllum inophyllum L. (Clusiaceae), and Syzygium grande (Wight) Walp. Myrtaceae showed highest survival rates (90.2-100\%) and canopy $\left(0.13-0.42 \mathrm{~m}^{2}\right)$ at twelve months after planting. These four species are believed to possess better anatomical, morphological, and physiological adaptations than the other six species. H. tiliaceus, F. superba, C. inophyllum, and S. grande appear to be the most promising species to use for revegetating tin-mined lands.
\end{abstract}

\section{Introduction}

Reliance on natural succession to restore sand tin tailings without any human intervention is impractical as it will take a long time before an effective cover is established (Mitchell, 1959; Ang, 1994; Nurtjahya et al., 2007a). Studies of natural regeneration on seven year old tin-mined land showed a dominance of species belonging to the families Cyperaceae and Poaceae; species belonging to Poaceae were dominant after 11 years, while shrub species of the family Myrtaceae were common on 38-year old tin-mined land (Nurtjahya et al., 2007a). The older tin-mined land tended to have soil with less sand and more silt and clay, a lower $\mathrm{C} / \mathrm{N}$ ratio, higher $\mathrm{P}_{2} \mathrm{O}_{5}, \mathrm{~K}_{2} \mathrm{O}, \mathrm{Ca}, \mathrm{Mg}, \mathrm{K}, \mathrm{Na}$, cation-exchange capacity (CEC), lower base saturation, and higher $\mathrm{Al}^{3+}$ (Nurtjahya et al., 2007a). No chemical toxicity to plants was reported (PPTA, 1996; E. Kusumastuti 2002, pers. comm.).

Standard sand tin tailings rehabilitation procedures practiced on the island involved planting with predominantly exotic Acacia mangium (Nurtjahya, 2001). Various sources of organic and inorganic matter to ameliorate the soil were examined (Siagian and Harahap, 1981; Puryanto, 1983; Sastrodihardjo, 1990; Naning et al., 1999; Nurtjahya, 2001) to increase CEC (especially in young tailings, Bendfeldt et al., 2001), water holding capacity, aggregate stability, and nutrient availability (Schroeder, 1996). The use of living mulch (Madjid et al., 1994; CBR, 2002) and the application of arbuscular mycorrhizal fungi were reported. A number of exotic tree species, widely used in rehabilitation programmes, were considered undesirable for all future rehabilitation efforts (Lamb and Tomlinson, 1994) as they may inhibit natural recolonization, although recent study showed that A. mangium was used successfully as a nurse-tree for reforestation on degraded sandy soils (Norisada et al., 2005). Selection of native tree species has been guided by information from natural succession observation (Nurtjahya et al., 2007a), vegetation types (Roemantyo et al., 2004), lists of plant invaders in revegetated tin-mined land (Latifah, 2000; Setiawan, 2003), and heath forest species (Norisada et al., 2005). 
Various indicators have been used to evaluate the success of revegetation. These include survival rate, plant growth, vertical and horizontal root growth, canopy, litter production, native species recolonization, and habitat improvement (D.J. Tongway et al., 2001, pers. comm.; Y. Setiadi, 2002, pers. comm.; Ludwidg et al., 2003), and the measurement of flora and fauna (Andersen and Sparling, 1997; Passel, 2000; Yin et al., 2000; Nurtjahya et al., 2007b). Survival rate is viewed as the most critical indicator (Lamb and Tomlinson, 1994).

The aim of this experiment was to identify the potential native tree species and amelioration amendments that are most useful in revegetating sand tin tailings. Results will aid the development of planting strategies that are effective for the re-establishment diverse native forests in as short a time as possible at places where the expense and high level of technical and professional supervision might be limited.

\section{Methodology}

\subsection{Study site}

The two hectares zero-year-old barren tin-mined land selected for the trial is located at Riding Panjang, Bangka Island, Indonesia (lat. 01 ${ }^{\circ} 59^{\prime} 53.46^{\prime}$ 'S; long. 106 06’45.32”E; $30 \mathrm{~m}$ asl.) (Figure 1). Mean annual rainfall (1996-2005) was $2408 \mathrm{~mm}$, and temperature ranges from $23.8-31.5^{\circ} \mathrm{C}$ with an average of $26.8^{\circ} \mathrm{C}$ (Pangkalpinang Meteorology Station, 2006). Each site was fenced and a $40 \mathrm{~cm}$ wide, $30 \mathrm{~cm}$ deep trench dug around the perimeter. Planting holes were a $30 \mathrm{~cm}$ cube filled with $30 \mathrm{~L}$ mineral soil, and $7 \mathrm{~L}$ saw dust-cow dung compost.

\subsection{Species selection}

A total of ten species with different percentages were selected for use in the trial. Calophyllum inophyllum L. (Clusiaceae) (11.7\%) and Hibiscus tiliaceus L. (Malvaceae) $(9.9 \%)$ are found in the Barringtonia formation (Backer and van den Brink, 1965) which is tolerant of salt spray, nutrient-deficient soil, and seasonal drought (Whitten et al., 2000). Calophyllum sp. and Syzygium sp. are common in padang vegetation, which is regarded as natural regeneration of degraded heath forest (Whitten et al., 2000). Macaranga sp. (Euphorbiaceae) (3.1\%) and Mallotus paniculatus (Lmk) M.A. (Euphorbiaceae) (3.1\%) are early pioneer species. Schima wallichii (DC) Korth. (Theaceae) (6.3\%) and Vitex pinnata (Verbenaceae) $(20.6 \%)$ are late pioneer species and seedlings of both species were recorded at 38-year old tin-mined land (Nurtjahya et al., 2007a). Syzygium grande (Wight) Walp. (Myrtaceae) (17.9\%) is common in the foothill coastal areas. Ficus superba Miq. (Moraceae) $(15.2 \%)$ is adapted to sandy and rocky coastal areas. Aporosa sp. (Euphorbiaceae) (3.1\%) commonly dominates in open and relatively dry areas. Syzygium polyanthum (Wight) Walp. (Myrtaceae) (9.0\%) is a nurse tree.

\subsection{Seedling preparation}

Seeds were germinated in sieved white sand in a green house with an average humidity of $76 \%$ and an air temperature of $30.4^{\circ} \mathrm{C}$. Seeds were dipped in $1 \%$ (v/v) humic acid solution for about 2-6 hours, or a hot sand dip for 20 minutes for V. pinnata seeds. Seedlings with at least three leaves were transplanted into polythene bags, and sprayed with leaf fertilizer Hyponex (red) $(0.25 \mathrm{~g} / \mathrm{L})$ every three weeks. Seedlings with a height of $35 \mathrm{~cm}$ were transferred to the environs of the study site for three weeks of acclimatization prior to planting.

\subsection{Experimental design}

The experiment consisted of a factorial randomized complete block design with two factors (planting density and soil treatment) and three blocks as replications. Each plot was $12 \times 12 \mathrm{~m}$ with $2 \mathrm{~m}$ spacing between plots and blocks. Three planting density levels were 1 x $1 \mathrm{~m}$ (10,000 seedlings/ha), 2 × $2 \mathrm{~m}$ (2500 seedlings/ha), and $4 \times 4 \mathrm{~m}$ (625 seedlings/ha), comprising a total of 3345 plants of ten species while the species composition among the three planting density treatments was similar. The planting arrangement was diamond or alternating one (Rachmawati et al., 1996; Parrotta and Knowles, 2001).

Five soil treatments were (i) control (T1), (ii) $500 \mathrm{~g}$ slime tailing powder under Lepironia articulata Rich. (T2), (iii) equal composition (1:1) of legumes Calopogonium mucunoides Desv. and Centrosema pubescens Bth. with $30 \mathrm{~kg} / \mathrm{ha}$ (T3), (iv) legumes and the application of $2.5 \%(\mathrm{v} / \mathrm{v})$ humic acid (T4), and (v) legumes and topsoil (T5). Legumes were fertilized with compost applied at rates of $200 \mathrm{~kg} / \mathrm{ha}$ and 5 tons/ha. The compost 
was a medium quality one with its $\mathrm{pH} 7.8$, C-organic $10.2 \%$, N-total $0.45 \%$, P-total $0.23 \%$, and K-total $0.32 \%$. Slimes tailings powder was prepared by crushing dried tin slime tailings which were available near the study site. It had $44 \%$ silt and $49 \%$ clay, $\mathrm{pH}=2.9, \mathrm{C} / \mathrm{N}=23, \mathrm{Ca}=1.26, \mathrm{Mg}=2.03, \mathrm{~K}=0.11$, and $\mathrm{Na}=0.63 \mathrm{cmol}(+) / \mathrm{kg}$, and $\mathrm{CEC}=17.2$. Humega humic acid $(6 \%$ liquid humic acid extract) was applied at three, seven, and eleven months after planting. Its $\mathrm{pH}$ was $8.9, \mathrm{C} / \mathrm{N}=26, \mathrm{Na}=0.93, \mathrm{Ca}=0.05$, and $\mathrm{Mg}=0.02 \mathrm{ppm}$. All plants were given 1 Lof 48 -hour fermented cow dung (10\% v/v) at three, seven, and eleven months after planting. Topsoil was collected from nearby lowland forest and the nearest Padang vegetation.

\subsection{Planting}

Seedlings were acclimatized in palm leaf-roofed green houses for three weeks before planting. Replacement of dead plants took place over three weeks after planting, and involved 241 plants or $7.2 \%$ of the total number of seedlings. Three to four pieces of coconut shell were placed around the collar of each seedling in the field. This reduces soil temperature by $2.1-4.3^{\circ} \mathrm{C}$ and significantly increases soil humidity between 0.8-12.2\% (Nurtjahya et al., 2007c). Every two weeks over the first three months, the plants were sprayed with leaf fertilizer Hyponex at a concentration of $0.25 \mathrm{~g} / \mathrm{L}$. The plants were watered every afternoon using water extracted from a nearby ex-mining pond (kolong) (Figure 2). The water quality fluctuated seasonally but remained within the normal range for plants with the highest reading of electric conductivity (EC) in the dry season $(1.9 \mathrm{mmhos} / \mathrm{cm})$. Its $\mathrm{pH}$ was 3.8 in dry season and 4.1 in rainy season, total cations $21.45 \mathrm{me} / \mathrm{L}$ in the dry season and $0.94 \mathrm{me} / \mathrm{L}$ in the rainy season, total anion $19.44 \mathrm{me} / \mathrm{L}$ in dry season and $1.04 \mathrm{me} / \mathrm{L}$ in the rainy season, silt $0 \mathrm{ppm}$ in the dry season and $115 \mathrm{ppm}$ in the rainy season, and no detected concentration of $\mathrm{Pb}, \mathrm{Cd}, \mathrm{Co}, \mathrm{Ni}$, and $\mathrm{Cr}$ cations except $0.03 \mathrm{~Pb}$ and $0.01 \mathrm{ppm} \mathrm{Ni}$ in the dry season. Several fish species live in the pond.

\subsection{Data collection and analysis}

Survival and sapling canopy diameter (maximum) of all individuals were measured at three, six, nine, and twelve months after planting.

\section{Results}

\subsection{Survival}

Survival of all individuals in all 45 plots declined from $98.8 \%$ at three months after planting, to $87.9 \%$ at six months, and to $71.8 \%$ at nine months, after which it remained the same until the end of the experiment, twelve months after planting. This mortality was mainly a result of poor survival of the pioneer species S. wallichii, Macaranga sp. and M. paniculatus, and the non-pioneer species Aporosa sp. Only a small percentage of seedling mortality was attributed to human disturbance. Survival rates above $90 \%$ at the end of the experiment was recorded for H. tiliaceus (100\%), F. superba (99.9\%), C. inophyllum (99.3\%), and S. grande (90.2\%) (Figure 3). Four species with the highest survival rates at three months were also the highest survivors at the end of the 12-month study. Species showing survival rates below $20 \%$ at the end of experiment included S. wallichii, Macaranga sp. M. paniculatus, and Aporosa sp.

\subsection{Tree canopy}

The four species with the highest canopy cover at the end of the experiment were $\mathrm{H}$. tiliaceus $\left(0.42 \mathrm{~m}^{2}\right)$, S. grande $\left(0.25 \mathrm{~m}^{2}\right), \mathrm{F}$. superba $\left(0.18 \mathrm{~m}^{2}\right)$, and C. inophyllum $\left(0.13 \mathrm{~m}^{2}\right)$ (Figure 4). The four plant species with the highest canopy cover at three months also had the highest canopy cover at the end of the experiment. Figure 4 shows the cover development of each species from three months after planting to twelve months. At six months after planting, the cover remained low, but increased thereafter.

The four species with the highest survival and canopy cover were H. tiliaceus, F. superba, C. inophyllum, and S. grande. This appears to be explained by the morphological adaptability to the environmental conditions of these species such as thicker cuticle and/or suberin. Some adaptations were reported in other study (Nurtjahya and Juairiah, 2006). Stomatal density of S. grande planted in tin tailing $\left(609.8 / \mathrm{mm}^{2}\right)$ was significantly greater than that of planted in undisturbed land $\left(539.1 / \mathrm{mm}^{2}\right)$, while stomatal density of 
V. pinnata showed the opposite. Leaf tissue ratio of V. pinnata planted in tin tailings $(0.10)$ was greater than that of planted in undisturbed land (0.09), while S. grande showed the opposite. Root conductivity ratio of S. grande planted in tin tailing (0.09) was significantly less than that of planted in undisturbed land (0.10) (Nurtjahya and Juairiah, 2006). Sonibare et al. (2006) reported that heavy lignification, multiple epidermis and the presence of hypodermis in some Ficus species from Nigeria were probable anatomical features of adaptation to xerophytic environments. Specific leaf area probably plays a significant role in effective assimilation and maintenance of heath forest productivity under stressful conditions (Miyamoto et al., 2007). On the other hand, some pioneer, nurse tree, or non-pioneer species were not adapted to barren sand tin tailings. Early or late pioneer (Cheah, 1995; M. Kanzaki, 2004, pers. comm.) is not always suitable to revegetate at any stages of abandoned tin-mined lands, although seeding early-successional shrubs may be an inexpensive strategy to accelerate recovery (ITTO, 2002). Macaranga spp. and Mallotus spp. were absent as colonizers in padang vegetation in Bangka Island (Whitten et al., 2000). Only species with heat tolerance or avoidance capacities may survive the heat stress in sand tailings (Ang and Ang, 1997).

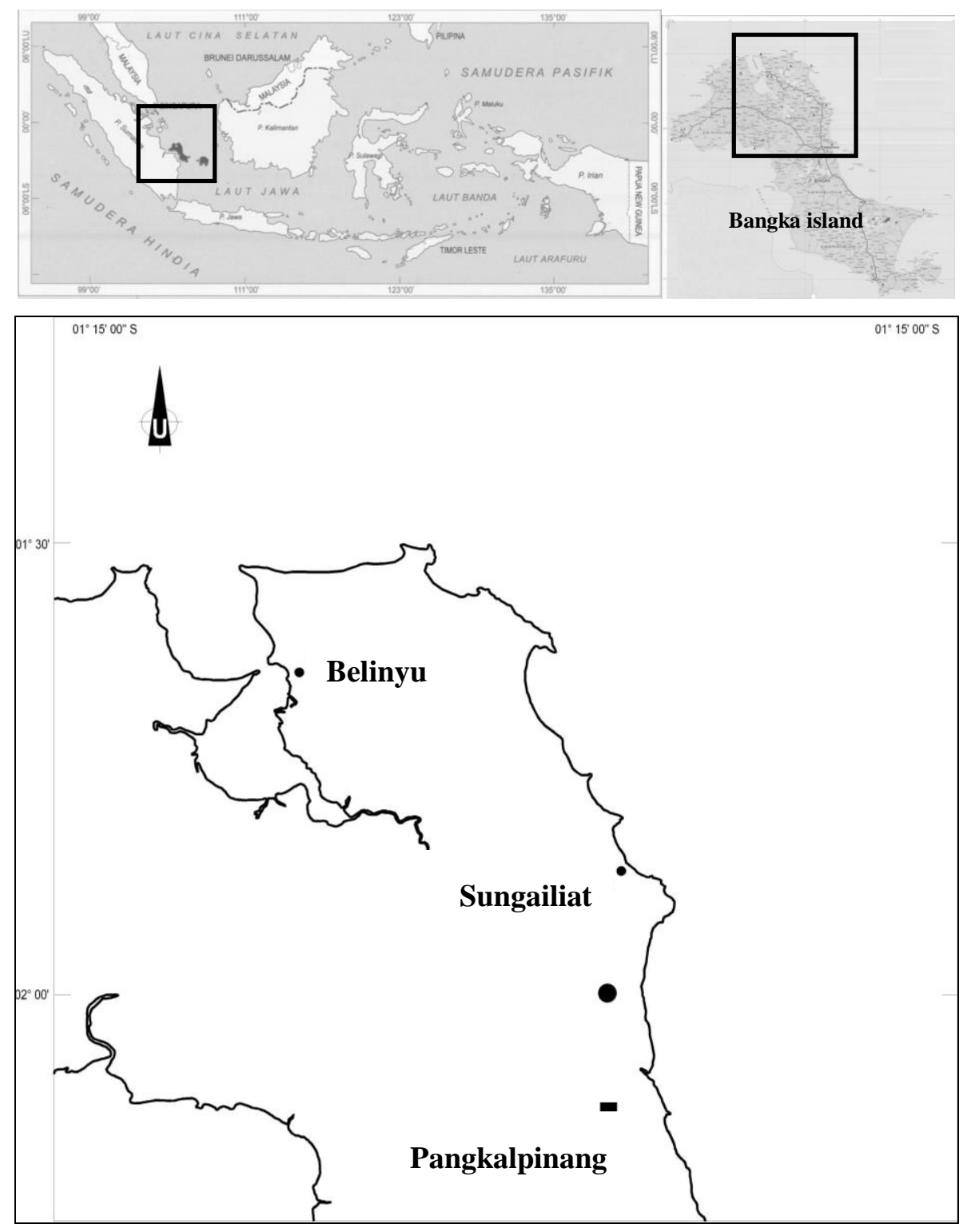

Figure 1 Study site $(\bullet)$ in the north-east of Bangka Island, Indonesia 

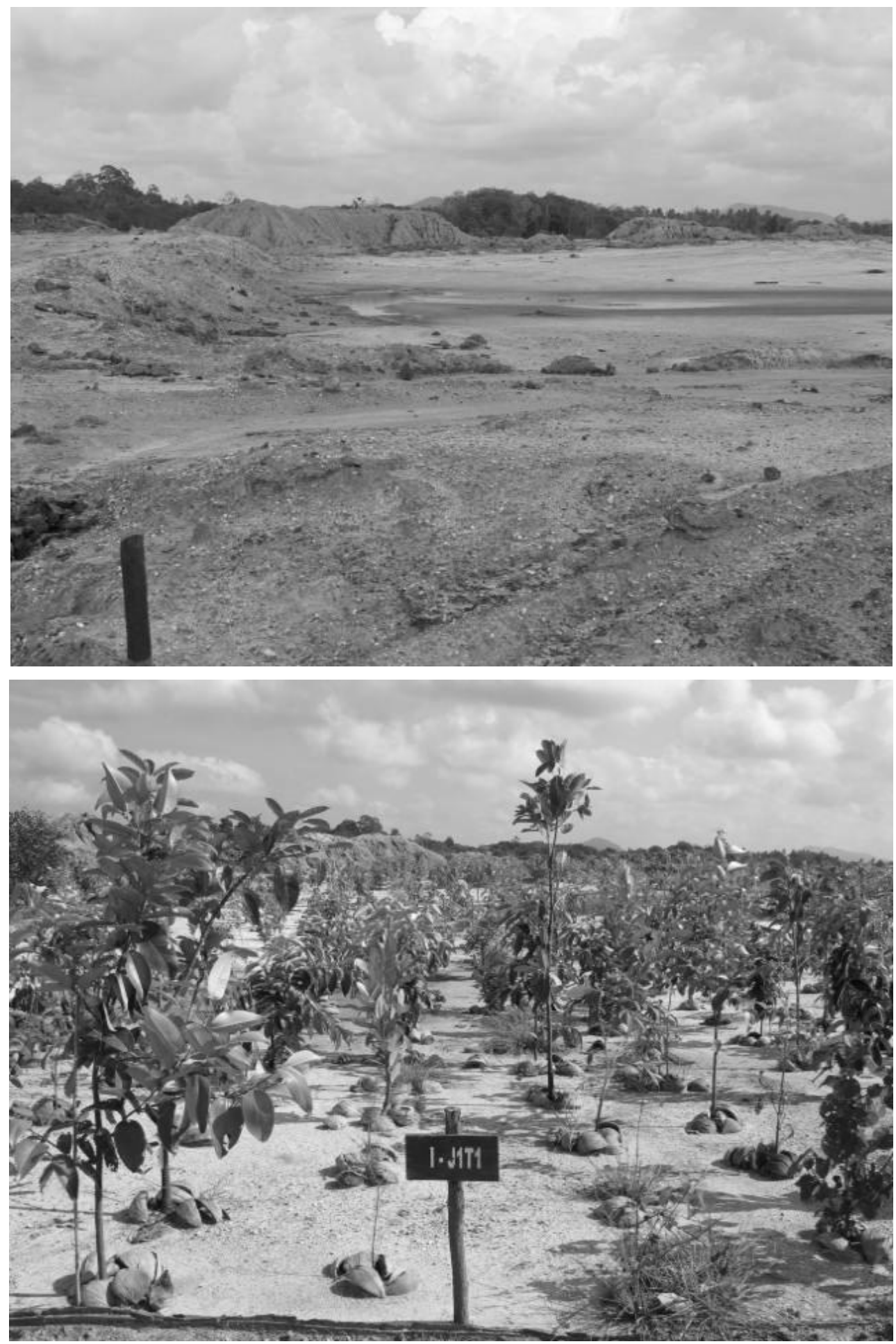

Figure 2 Barren sand tin tailing before planting (top); highest planting density ( $1 \times 1 \mathrm{~m})$ and no soil treatment at the end of experiment (bottom) 


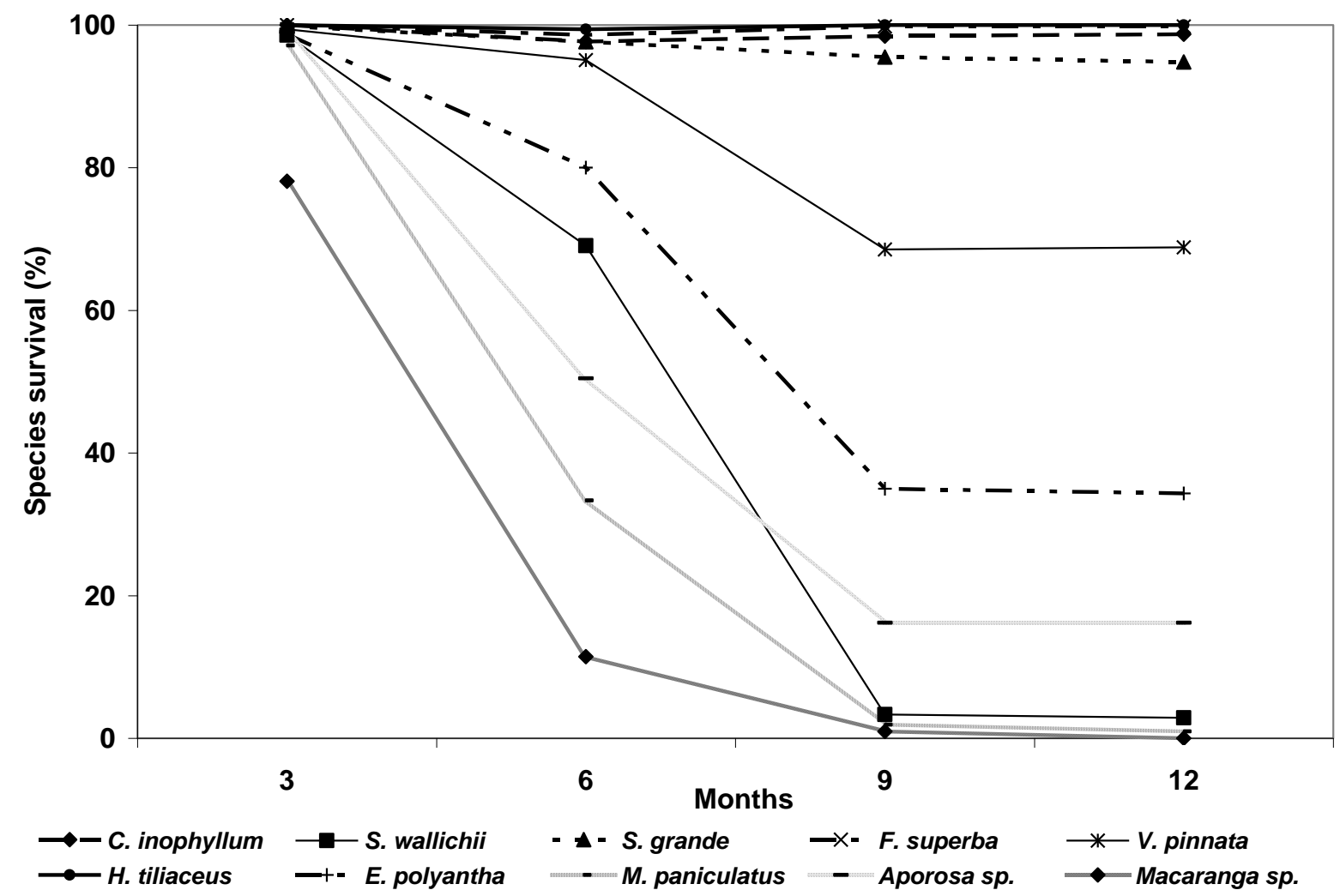

Figure 3 The average species survival at three, six, nine, and twelve months after planting

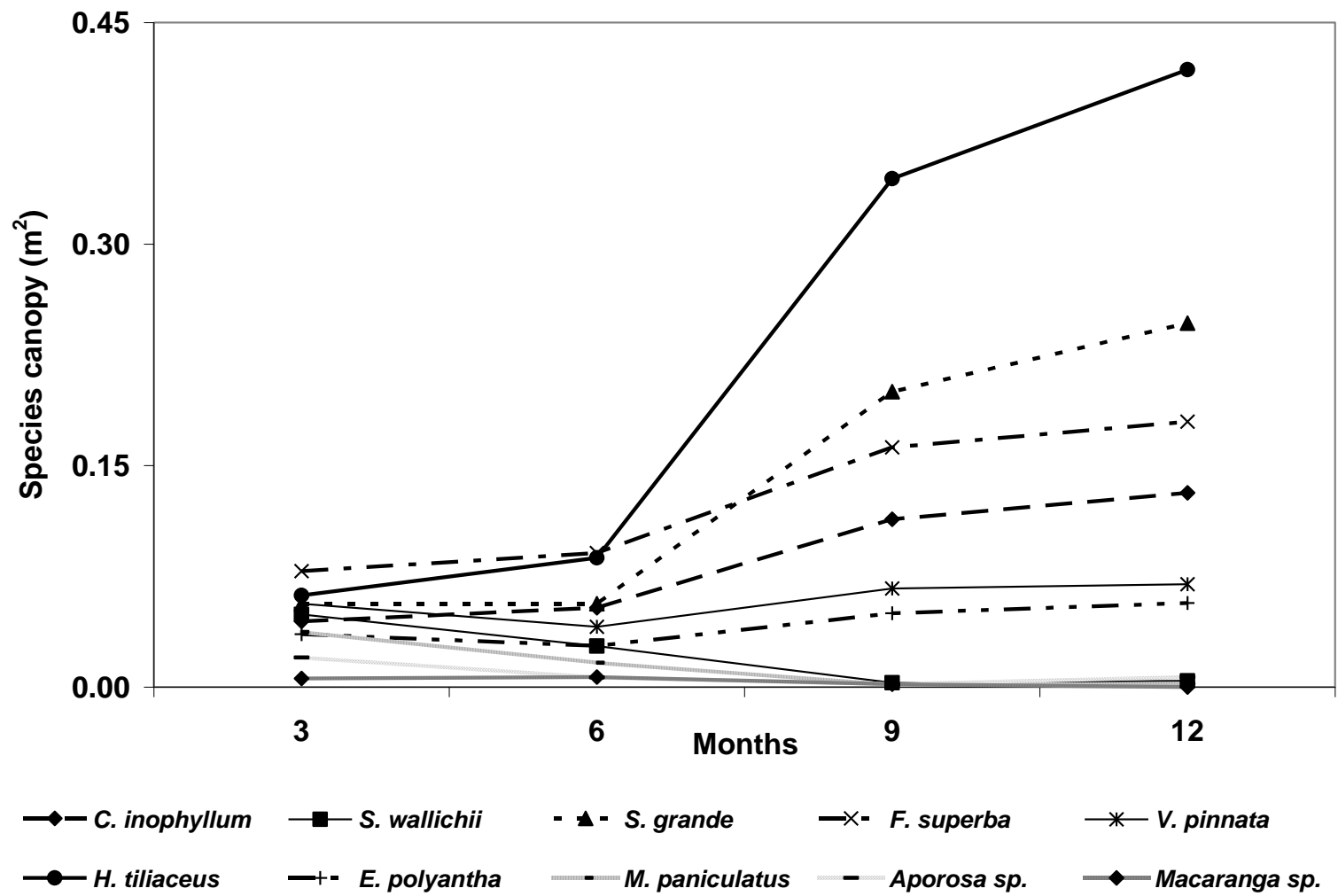

Figure 4 The average species canopy area at three, six, nine, and twelve months after planting 


\section{Conclusions}

Four of ten native tree species i.e. H. tiliaceus, F. superba, C. inophyllum, and S. grande showed highest survival rates $(90.2-100 \%)$ and highest cover development $\left(0.13-0.42 \mathrm{~m}^{2}\right)$ at twelve months after planting. Evidence suggests that these four species have better anatomical, morphological, and physiological adaptations than the other six species and are therefore the most promising of the ten native tree species for revegetating tin-mined lands. Based on different adaptation among native trees planted in the experiment, minimal water demand and evapotranspiration should be measured in further selections of native tree species as candidates for revegetating sand tin tailing. These should be sought within the Barringtonia formation of coastal mixed forest, and Padang vegetation.

\section{Acknowledgements}

The first author gratefully acknowledges the funding of this research by the International Tropical Timber Organization (039/03A). The authors thank the Directorate General of Higher Education, Ministry of Education, Republic of Indonesia for partially funding the field research, and PT Tambang Timah, Bangka, for permitting access to the mining complex area for research purposes and also provided financial support, and to Bapak Sutrisno Tatedegaat, Bapak Hanafi Sulaiman, and Bapak Setiabudi Abdullah for their assistance. The authors would like to thank Dr J.A. Parrotta for his support and advice, Wistaria, Roni, Kusmah, and Muhammad for field assistance, and the people of Riding Panjang hamlet for their support. Special thanks are also due to all reviewers for their valuable comments on the manuscript.

\section{References}

Andersen, A.N. and Sparling, G.P. (1997) Ants as indicators of restoration success: relationship with soil microbial biomass in the Australian seasonal tropics. Restoration Ecology 5, pp. 109-114.

Ang, L.H. (1994) Problems and prospects of afforestation on sand tin tailings in peninsular Malaysia. Journal of Tropical Forest Science 7, pp. 87-105.

Ang, L.H. and Ang, T.B. (1997) Greening the tin tailing areas in Malaysia. In: Conference on Forestry and Forest Products Research.

Backer, C.A. and van den Brink, R.C.B. (1965) Flora of Java, Vol. 2. Angiospermae, families 111-160. NV P Noordhoff, Groningen.

Bendfeldt, E.S., Burger, J.A. and Daniels, W.L. (2001) Quality of amended mine soils after sixteen years. Soil Science Society American Journal 65, pp. 1736-1744.

CBR - Centre for Biotechnology Research (2002) Effect of bio-organic on soil and plant productivity improvement of post tin mine site at PT Koba Tin project area, Bangka. Bogor Agricultural University, Bogor.

Cheah, L.C. (1995) Pioneer species for fast growing tree plantations in Malaysia - an evaluation. FRIM Technical Information No. 53.

ITTO (2002) ITTO guidelines for the restoration, management and rehabilitation of degraded and secondary tropical forests. ITTO Policy Development Series No. 13.

Lamb, D. and Tomlinson, M. (1994). Forest rehabilitation in the Asia-Pasific region: past lessons and present uncertainties. Journal of Tropical Forest Science 7, pp. 157-170.

Latifah, S. (2000) Keragaan pertumbuhan Acacia mangium Willd. pada lahan bekas tambang timah (studi kasus di areal kerja PT Timah Tbk.) (tesis, Institut Pertanian Bogor, Bogor).

Ludwig, J.A., Hindley, N. and Barnett, G. (2003) Indicators for monitoring minesite rehabilitation: trends on waste-rock dumps, Northern Australia. Ecology Indicators 3, pp. 143-153.

Madjid, N.M., Hashim, A. and Abdol, I. (1994) Rehabilitation of ex-tin mining land by agroforestry practice. Journal of Tropical Forest Science 7, pp. 113-127.

Mitchell, B.A. (1959) The ecology of tin mine spoil heaps. Part I sand and gravel tailings. Malayan Forestry 22, pp. 111-132.

Miyamoto, K., Rahajoe, J.S. and Kohyama, T. (2007) Forest structure and primary productivity in a Bornean heath forest. Biotropica 39, pp. 35-42.

Naning, M.I., Diha, M.A. and Gofar, N. (1999) Perbaikan sifat kimia bahan tailing asal lahan pasca penambangan timah dan pertumbuhan tanaman jagung dengan pemberian bahan organik dan zeolit. In: Prosiding Seminar Hasil Penelitian Universitas Sriwijaya, Maret 1999.

Norisada, M., Hitsuma, G. and Kuroda, K., Yamanoshita, T., Masumori, M., Tange, T., Yagi, H., Nuyim, T., Sasaki, S. and Kojima, K. (2005) Acacia mangium, a nurse tree candidate for reforestation on degraded sandy soils in the Malay Peninsula. Forest Science 51, pp. 498-510. 
Nurtjahya, E. (2001) Revegetation on tin post mining area in Bangka Island (bibliographical review). Indonesian Mining Journal 7, pp. 32-37.

Nurtjahya, E. and Juairiah, L. (2006) Struktur anatomi dan karakter fisiologi tanaman pionir di lahan pasca penambangan timah di Riding Panjang, Bangka. Universitas Bangka Belitung, Sungailiat, 31 p.

Nurtjahya, E., Setiadi, D., Guhardja, E., Muhadiono and Setiadi, Y. (2007a) Succession on tin-mined land in Bangka Island in The Seventh International Flora Malesiana Symposium, 17-22 June 2007, Leiden, The Netherlands, $14 \mathrm{p}$.

Nurtjahya, E., Setiadi, D., Guhardja, E., Muhadiono and Setiadi, Y. (2007b) Potensi Collembola sebagai indikator revegetasi tailing timah di pulau Bangka. Jurnal Ilmu-ilmu Pertanian Indonesia 9, pp. 113-123.

Nurtjahya, E., Setiadi, D., Guhardja, E., Muhadiono and Setiadi, Y. (2007c) Sabut kelapa sebagai mulsa pada revegetasi tailing timah di pulau Bangka. Eugenia 13, pp. 366-382.

Pangkalpinang Meteorology Station (2006) Data iklim Bangka 1996-2005, 10 p.

Parrotta, J.A. and Knowles, O.H. (2001) Restoring tropical forests on lands mined for bauxite: examples from the Brazilian Amazon. Ecology Engeneering 17, pp. 219-239.

Passell, H.D. (2000) Recovery of bird species in minimally restored Indonesian tin strip mines. Restoration Ecology 8 , pp. 112-118.

PPTA - Pusat Penelitian Tanah dan Agroklimat (1996) Laporan akhir penelitian studi upaya rehabilitasi lingkungan penambangan timah. Pusat Penelitian Tanah dan Agroklimat, Bogor.

Puryanto, E. (1983) Rehabilitasi tanah pasir kuarsa eks tambang timah pulau Bangka dengan bahan-bahan alamiah untuk budidaya tanaman jambu monyet (Anacardium occidentale L.). skripsi, Institut Pertanian Bogor, Bogor.

Rachmawati, I., Karyawan, K.A. and Sinaga, M. (1996) Pengaruh model tanam terhadap pertumbuhan beberapa jenis pohon serba guna. Buletin Penelitian Kehutanan BPK Kupang 1, pp. 102-108.

Roemantyo, R.E., Uji, T., Noerdjito, M. and Utaminingrum, H.I.P. (2004) Indonesia biodiversity information system (IBIS) case study: vegetation diversity of Bangka Island, Bangka-Biliton, Indonesia. In: International Symposium 2004 Asian Plant Diversity and Systematics, Japan: July 29-August 2, 2004.

Sastrodihardjo, S. (1990) Pengaruh pemberian bahan organik dan polimer alam serta sintetik terhadap beberapa sifat fisik dan kimia tanah tailing tambang 25 wilasi Pangkalpinang Unit Penambangan Timah Bangka (UPTB). [skripsi] Institut Pertanian Bogor, Fakultas Pertanian, Bogor.

Schroeder, P.H. (1996) Restoration of prime farmland disturbed by mineral sand mining in the upper coastal plain of Virginia [thesis]. Virginia Polytechnic Institute and State University. http://scholar.lib.vt.edu/theses/public/etd303112202974780/ etd-title.html. Cited 14 Dec 2003.

Setiawan, I.E. (2003) Evaluasi tingkat keberhasilan revegetasi pada lahan bekas tambang timah PT Koba Tin, Koba, Bangka Belitung. skripsi, Institut Pertanian Bogor, Bogor.

Siagian, Y.T. and Harahap, R.M.S. (1981) Hasil pendahuluan percobaan pemilihan jenis-jenis pohon pada lahan kolong pasir kuarsa di Dabo, Singkep [Laporan]. Laporan Balai Penelitian Hutan No. 384. Balai Penelitian Hutan, Bogor.

Slik, J.W.F. (2001) Macaranga and Mallotus (Euphorbiaceae) as indicators for disturbance in the lowland dipterocarp forests of East Kalimantan, Indonesia. The Tropenbos Foundation, Wageningen.

Sonibare, M.A., Jayeola, A.A. and Egunyomi, A. (2006) Comparative leaf anatomy of Ficus Linn. species (Moraceae) from Nigeria. Journal of Applied Science 6, pp. 3016-3025.

Whitten, A.J., Damanik, S.J., Anwar, J. and Hisyam, N. (2000) The ecology of Sumatra. Periplus Editions (HK) Ltd, Singapore.

Yin, B., Crowley, D., Sparovek, G., De Melo, W.J. and Borneman, J. (2000) Bacterial functional redundancy along a soil reclamation gradient. Applied and Environmental Microbiology 66, pp. 4361-4365. 